UDC 631.92

(C) 2020

\title{
Causes of Shatsk Lakes shoaling and ways of regulation of their water balance
}

\author{
Romashchenko M. ${ }^{1}$, Yatsiuk M. ${ }^{2}$, Sydorenko O. ${ }^{3}$, Nechai O. ${ }^{4}$, Voropai H. ${ }^{5}$, Nasedkin I. ${ }^{6}$, Tsvetova O. \\ Saidak R. ${ }^{8}$ \\ Institute of Water Problems and Land Reclamation of NAAS, Kyiv, Ukraine \\ 37 Vasylkivska Str., Kyiv, 03022, Ukraine

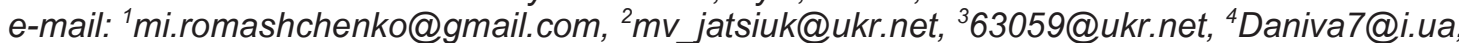 \\ 5voropaig@ukr.net, ${ }^{6} n a s e d k i n 12 @ u k r . n e t, 7 w a t e r 22019 @ u k r . n e t, 8 s a i d a k$ r@ukr.net \\ ORCID: ${ }^{1}$ 0000-0002-9997-1346, ${ }^{2}$ 0000-0002-4329-4382, ${ }^{3} 0000-0002-7377-6809,{ }^{4} 0000-0003-0365-1864$, \\ ${ }^{5} 0000-0002-5004-0727,{ }^{6} 0000-0003-0616-6514,{ }^{7} 0000-0001-9911-9316,{ }^{8} 0000-0002-0213-0496$
}

Goal. To establish reliable reasons for the shallowing of the Shatsk Lakes cascade based on observational materials and scientific generalizations. Methods. Analytical and field research methods are used. The method of work included a reconnaissance survey of the monitoring network, control measurements of groundwater levels, hydrological measurements, analytical calculations of water balances. Results. The process of Shatsk Group lakes' shallowing is caused by a set of factors, the main of which is global climate change. The combination of climate aridization with the inefficient functioning of reclamation systems, the development of the Belarusian «Khotyslavske» deposit, intensive agriculture, seasonal recreation, and irrational water use by the local population have led to negative environmental consequences. According to forecast data for 2020, the surface water level in Lake Svityaz is expected to be $37 \mathrm{~cm}$ lower than usual. That is why all traditional approaches should be reviewed and the focus should be on the accumulation of water resources. Analysis of the functioning of the Kopayiv drainage system showed that its reconstruction and modernization into a drainage and humidification system is one of the main means of water regulation (accumulation, redistribution, minimization of discharge) and conservation of water resources of the Shatsk Lake. There is an urgent need to protect the territory and use its natural objects by the established international laws. Conclusions. The introduction of measures for the rational use and protection of water resources, as well as the implementation of water use within the legal framework in compliance with environmental standards and safety measures, will significantly improve water management and promote the sustainable operation of nature reserves in the Shatsk Lake.

Key words: global climate change, aridization, reclaimed lands, anthropogenic load, reclamation drainage systems, recreation, Svityaz.

DOI: https://doi.org/10.31073/agrovisnyk202008-01

In the territory of Shatsk National Nature Park (SNP) there is one of the largest and deepest lakes in Ukraine - Svityaz, which in recent years has drastically become shallow. At the end of 2019, the water receded from its shores by tens of meters [1]. This has become a potential threat to the region's recreational and health capacity and an indicator of the declining of water supply of Shatsk Lakes area in general. Therefore, specifying the main factors of abrupt shallowing of Svityaz Lake, substantiation of the main optimal conditions for increasing environmental sustainability and balanced development of Shatsk Lakes area, as well as improving water supply and water quality, preserving aquatic ecosystems as unique components of the environment have become extremely important tasks.

According to the results of the previous researches conducted by the Institute of Water Problems and Land Reclamation of NAAS, Shatsk National Nature Park, Eastern European National University named after Lesya Ukrainka, National University of Water Management and Nature Resources Use, Lviv National University named after Ivan Franko, Institute of Physics and Mechanics named after G.V. Karpenko and other institutions identified a number of reasons for the decrease in water supply of Shatsk Lakes area [2, 3].

Thus, the Institute of Hydraulic Engineering and Land Reclamation of NAAS (now the Institute of Water Problems and Land Reclamation of NAAS (IWPLR) based on the generalized monitoring observations on the surface and groundwater regimes determined that the periods of $1971-1983$ and $2005-2014$ were stable as to the formation of annual water budgets, but with certain deviations from the average values of individual components. In the water-budget input the main components are infiltration recharge and inflow of pressure water, in the water-budget output they are - evaporation losses, which correspond to the previously established for this area infiltration-pressure evaporation type of water budget formation [4].

It is known that Svityaz Lake is located in the transit zone of underground flow, which moves from south to north and northeast from the main feeding zone (Volyn Upland) to the area of groundwater discharge (the valley of the Mukhovets River). The analysis of long-term dynamics of water level in Svityaz Lake testifies that the highest average values fall on the period of 2007-2010, and the lowest ones - on the period of 1973-1974, i.e. after drainage works and active use of drained lands until the mid-90s of the twentieth century. Later, despite the increase in evaporation, the water level generally increased and fluctuated according to the seasons of the year cyclically in the "dry-wet" years, depending on weather conditions. 
In recent years, against a backdrop of global warming, there has been a sharp decline in water levels of soil and pressure horizons and, accordingly, water levels in all surface watercourses and reservoirs of the study region, including Svityaz Lake.

Purpose of the research is to analyze the current state, conditions and the mechanism of water supply formation of Shatsk Lake area, to determine the main factors of lakes shallowing, substantiation of restoration ways and ensuring sustainability of water balance formation in this area.

Materials and methods of the research. Analytical and field research methods were used. The methodology of the research included the reconnaissance survey of the monitoring network, check measurements of groundwater levels, hydrological measurements and analytical calculations of water balances.

Results of the research. The results of the previous studies suggest that the current process of Shatsk lakes shallowing is due to a set of factors. It is extremely important not only to find out all the factors of influence, but also to rank them according to the significance of the influence on the formation and state of the area water balance.

Global climate change. The studies have shown [5-9] that in recent years the impact of global warming has become more pronounced, especially due to rising temperatures. Thus, according to the Svityaz meteorological station, the average annual air temperature in 2018 was $+9.8^{\circ} \mathrm{C}$, i.e. it was $1.4^{\circ} \mathrm{C}$ higher than the long-term average one. The maximum temperature was observed in August $\left(+32^{\circ} \mathrm{C}\right)$, the minimum - in March $\left(-18.2^{\circ} \mathrm{C}\right)$. In 2019 , June was abnormally hot with an average monthly temperature of $22.3^{\circ} \mathrm{C}$ and the maximum one of $35.2^{\circ} \mathrm{C}$. In July, the average temperature was $19^{\circ} \mathrm{C}$ and the maximum one was $36.1^{\circ} \mathrm{C}$. The average daily temperature in the summer of 2018 was $20.1^{\circ} \mathrm{C}$, which is over the limits by $2.4^{\circ} \mathrm{C}$ (limit $17.7^{\circ} \mathrm{C}$ ), and in 2019 it was $20.5^{\circ} \mathrm{C}$, which is over the limits by $2.8^{\circ} \mathrm{C}$. The minimum temperature was observed in January $\left(-13.3^{\circ} \mathrm{C}\right)$.

Precipitation in 2018 was $541.7 \mathrm{~mm}$, which is $44 \mathrm{~mm}$ less than the average long-term amount in the period of 1985-2017, and in 2019 - $561.3 \mathrm{~mm}$, which is $24.4 \mathrm{~mm}$ less than the average long-term amount. The analysis of the data from the Svityaz meteorological station for the period of 1985 - 2019 showed that air temperature and precipitation during the period of 2018-2019 differed significantly from long-term data. First of all, this applies to a significant increase in temperature in the first half and in general in 2018 (by $1.4^{\circ} \mathrm{C}$ ) (Figs. 1, 2)

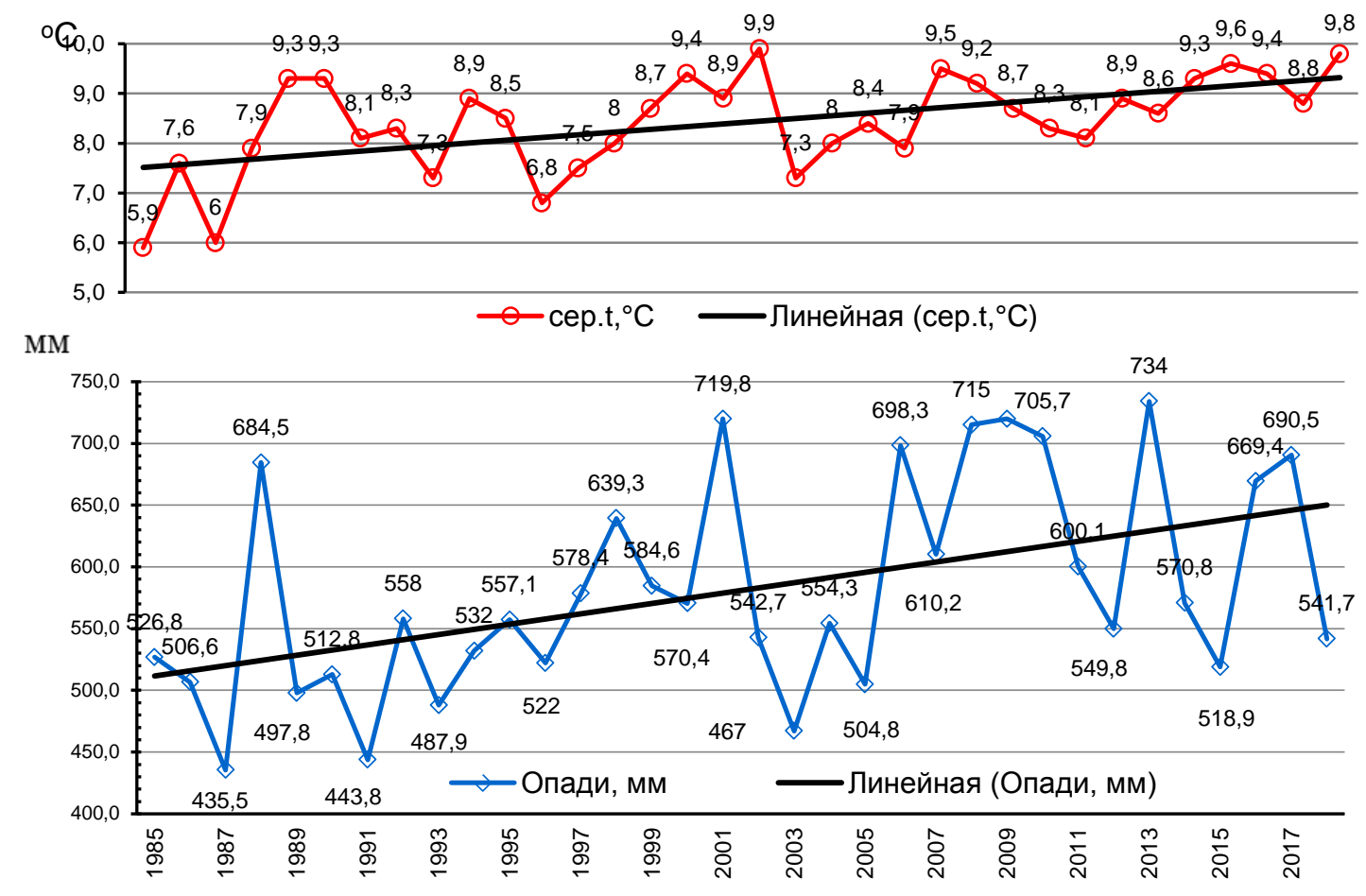

Fig. 1. Dynamics of average annual air temperature and precipitation from 1985 to 2019 according to Svityaz meteorological station: $a-\ldots$ average temperature, ${ }^{\circ} \mathrm{C}, \ldots$ - trend line, ${ }^{\circ} \mathrm{C} ; b-\ldots-$ precipitation, mm, $\ldots$ trend line, $\mathrm{mm}$ 


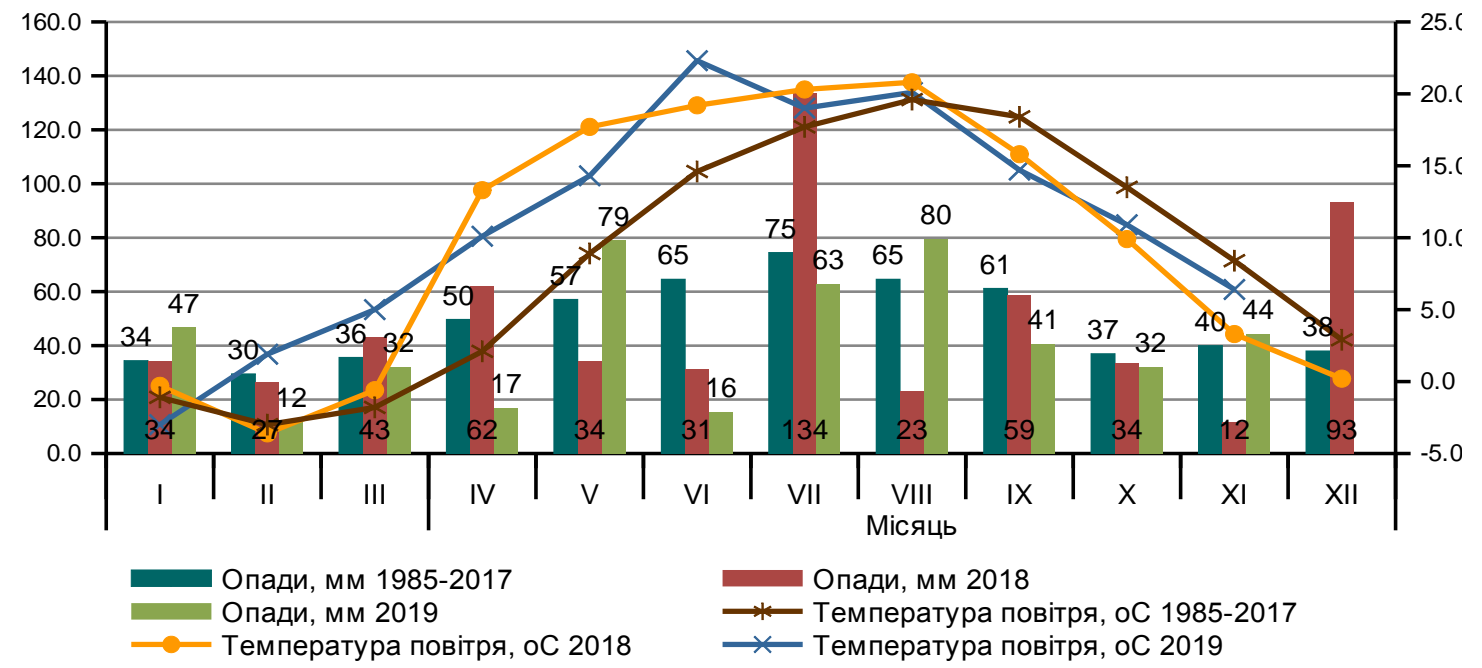

Fig. 2. Dynamics of air temperature and precipitation during the year of 2018-2019 period based on the average long-term data according to Svityaz meteorological station:... - precipitation, $\mathrm{mm}, 1985-2917 ; \ldots$ precipitation, mm, 2018; ... - precipitation, $\mathrm{mm}, 2019 ; \ldots$ - air temperature, ${ }^{\circ} \mathrm{C}, 1985-2917 ; \ldots$ - air temperature, ${ }^{\circ} \mathrm{C} 2018 ; \ldots$ - air temperature, ${ }^{\circ} \mathrm{C}, 2019$.

Significant warming in the first half of 2018 led to a change in the natural moisture supply of the area. The hydrothermal coefficient (HTC), which characterizes this exponent, in 2018 decreased up to 1.01 , and in 2019 - up to 0.95 having an average its value for the Polissya zone of about 1.4 .

As for the water level (WL) in Svityaz Lake, on average for the period of 1994-2018, its highest values were observed in May - $163.49 \mathrm{~m}$, and the lowest ones - in October-November - 163.32-163.31 m (Fig. 3). In 2019, in August-September, its absolute minimum was recorded, and in October-December of the same year, the WL fell below the minimum value, which was recorded during the period of 1994-2018, and amounted to $162.98-162.94 \mathrm{~m}$. In the last 25 years, the minimum WL in October-December decreased by $27-19 \mathrm{~cm}$ compared to the average one, in 2019 it decreased by $34-37 \mathrm{~cm}$.

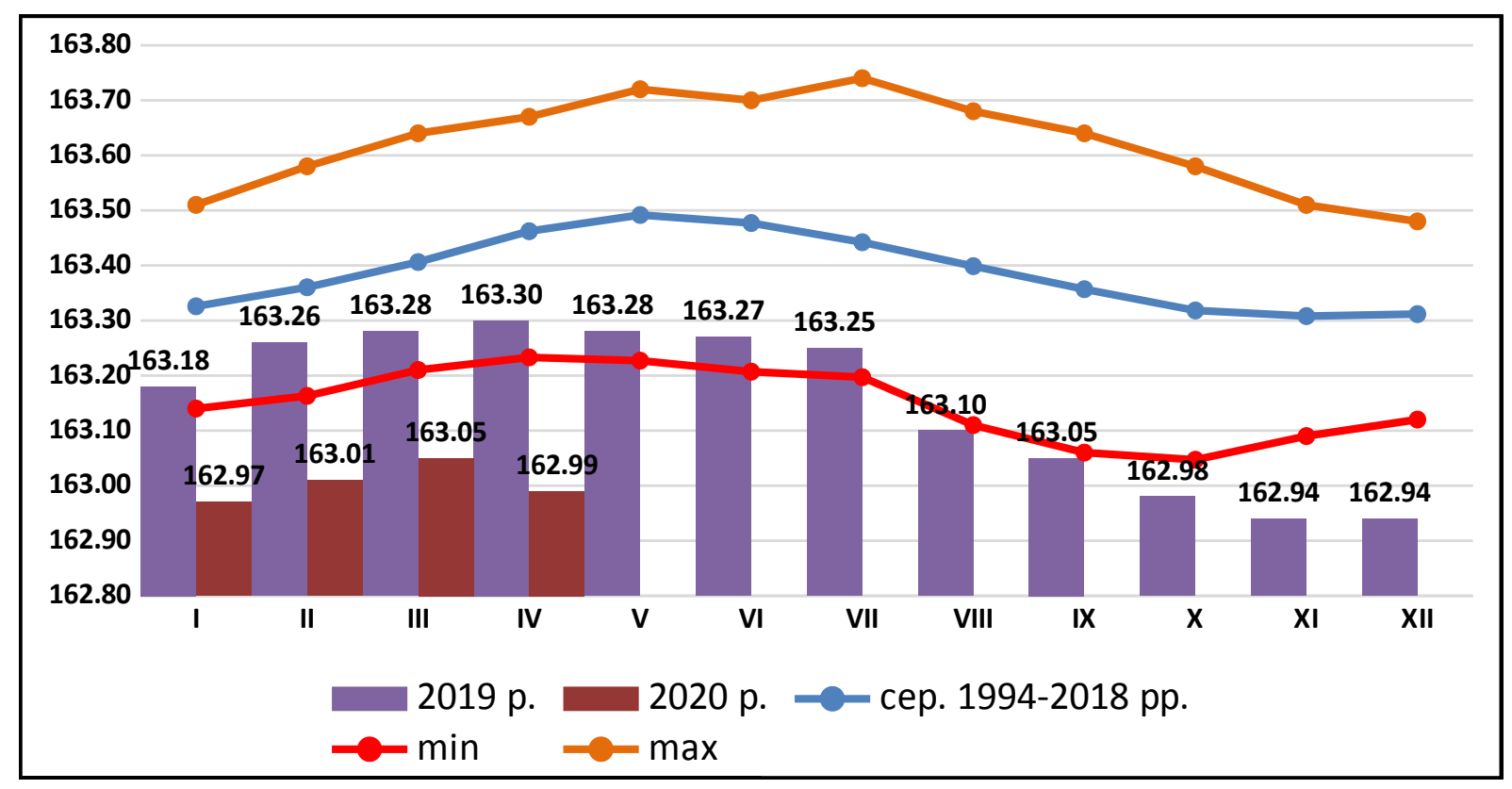

Fig. 3. The dynamics of the average monthly WL in Svityaz Lake in the period of 1994-2019, $m$ above sea level:... - 2019; ... - 2020; ... - average for 1994-2018; .. - min; ... - max

According to forecast calculations in August, in view of the general seasonal dynamics, WL in Svityaz Lake will decrease up to $163.11 \mathrm{~m}$, and in September-October - up to 163.09-163.07 m. That is, it will be 25$27 \mathrm{~cm}$ lower than the average long-term one, but 6-7 cm higher compared to the same period in 2019 ( Fig. $4)$. 


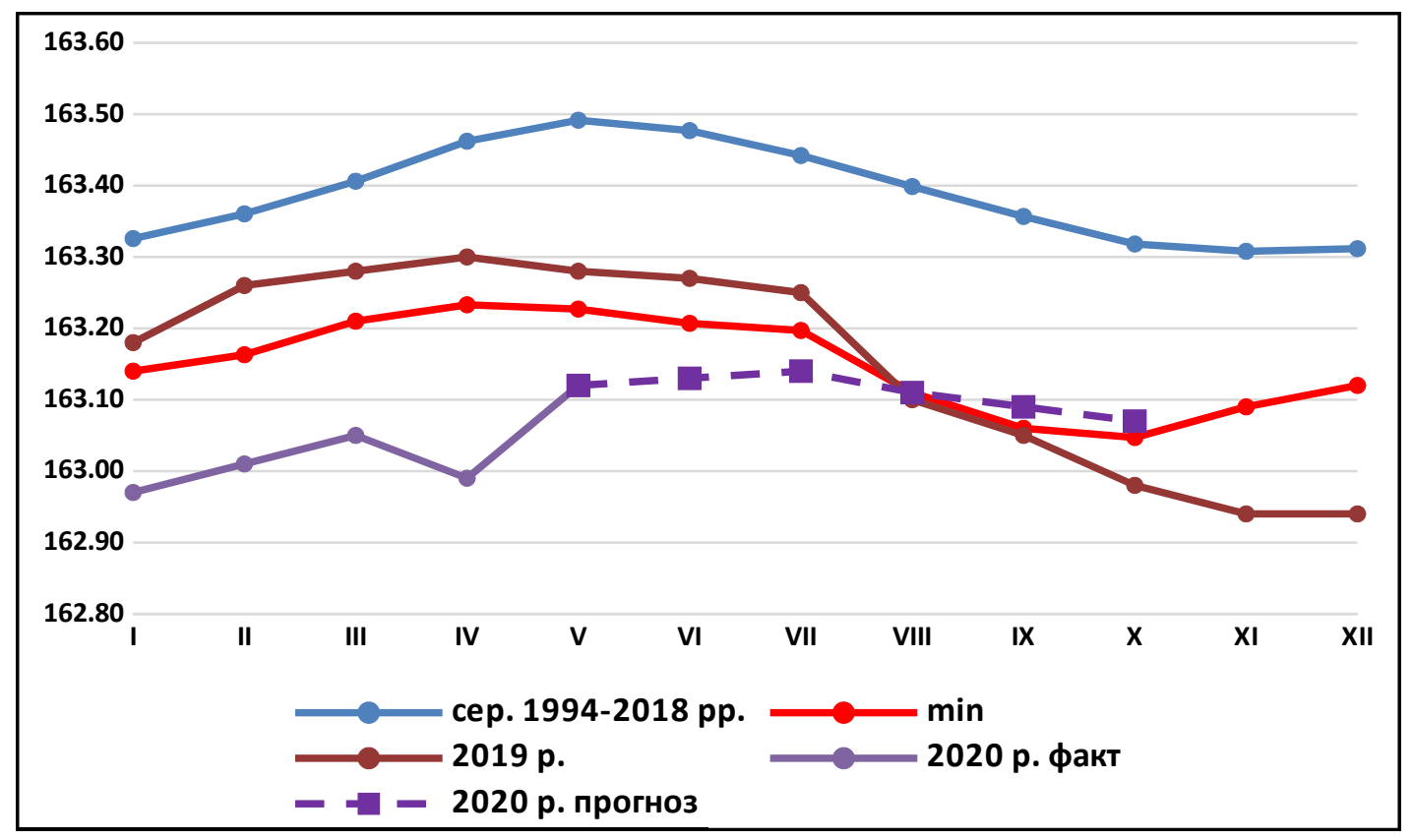

Fig. 4. Forecast of the dynamics of WL in Svityaz Lake for May-October 2020, m: - average for 1994$2018 ;. . .2019 ; . .$. - 2020, forecast; ... - 2020, in fact, ... - $\min$

In 2020 , with a probability of up to $15 \%$, it is possible the seasonal dynamics of WL increase will keep up providing the amount of precipitation in July-September of 2020 is 1.5-2 times higher than the long-term values. This amount of precipitation can increase the WL by 2-4 cm in August, by $4-5 \mathrm{~cm}$ in September, and by $6-9 \mathrm{~cm}$ in general. But even having such an unlikely scenario, the WL in the lake in October this year will be $15-20 \mathrm{~cm}$ lower than usual.

Hydraulic interconnection of natural waters of Shatsk Lakes area. Aquifers and natural complexes of Shatsk Lakes area have a close hydraulic relationship, which is confirmed by the close position of their static levels and the similarity of the chemical composition of water, as well as the absence of calmatation zones in the areas where groundwater is fed by the overflow of pressure water of Upper Cretaceous aquifer [ 2, 3, 10].

Analysis of the water balance of Svityaz Lake (Table 1) shows that until 2013 its main fed components were precipitation (50-80\%) and pressure water feeding (20-50\%), and expenditure components evaporation (up to $90 \%$ ), feeding of soil flow (10-15\%) and surface runoff (5-10\%). The pressure water, the inflow of which has always risen with increasing water discharge and lowering the lake level was and is a stabilizing factor in keeping water balance. This confirms the calm nature of the graph of lake level fluctuations without extreme ups and downs (see table).

Water balance of Svityaz Lake for the periods of 1970-1976 and 2016-2019

\begin{tabular}{|c|c|c|c|c|c|c|c|c|c|}
\hline \multirow[b]{2}{*}{ Year } & \multicolumn{4}{|c|}{ Feeding the lake due to, $\mathrm{mm}$} & \multicolumn{4}{|c|}{ Water discharge due to, $\mathrm{mm}$} & \multirow[b]{2}{*}{$\begin{array}{c}\text { Level } \\
\text { change, } \\
\text { mm } \\
\text { (balance) }\end{array}$} \\
\hline & $\begin{array}{l}\text { Precip } \\
\text { itation }\end{array}$ & $\begin{array}{c}\text { Pressure } \\
\text { water } \\
\text { feeding }\end{array}$ & $\begin{array}{c}\text { Effluent } \\
\text { seepage }\end{array}$ & $\begin{array}{c}\text { Surface } \\
\text { water } \\
\text { input }\end{array}$ & $\begin{array}{c}\text { Evaporat } \\
\text { ion }\end{array}$ & $\begin{array}{l}\text { Water } \\
\text { downstr } \\
\text { eam }\end{array}$ & $\begin{array}{l}\text { Water } \\
\text { flow to } \\
\text { the } \\
\text { groun } \\
\text { dwater }\end{array}$ & $\begin{array}{c}\text { Surface } \\
\text { runoff }\end{array}$ & \\
\hline $\begin{array}{l}1970- \\
1976\end{array}$ & 585 & 115 & 20 & 45 & 523 & 一 & 23 & 188 & 31 \\
\hline 2016 & 678 & 359 & 45 & 42 & 805 & - & 205 & 44 & 70 \\
\hline 2017 & 690 & 237 & 59 & 62 & 924 & - & - & 44 & 80 \\
\hline 2018 & 586 & 500 & 40 & - & 642 & - & 575 & 59 & -150 \\
\hline 2019 & 462 & 351 & 35 & 20 & 845 & - & 259 & 44 & -280 \\
\hline
\end{tabular}

The period from 2013 turned out to be abnormal in the formation of the water balance of Svityaz Lake, when a steady downward trend in the lake level was formed with a period of its relative stabilization in 20152018 and a sharp decline to the multi-year low in 2019.

Khotyslavky Open Pit Mine (Republic of Belarus). The area where the open pit is being excavated is located topographically lower than the system of lakes, and therefore the excavation of the open pit will 
inevitably lead to increased groundwater runoff in its direction, which will cause changes in the hydrological regime in large areas $[4,10]$.

Today the excavation area is 4.5 hectares, and the depth of sand extraction has reached $10-12 \mathrm{~m}$. According to the project, the maximum depth of chalk extraction will be $45 \mathrm{~m}$. That is, the zones of active water exchange and increased fracturing of fractured karst rocks will be exploded, which will require significant water removing and will affect the ecological condition of the surrounding areas, including Shatsk NNP. Given that the projected duration of chalk and sand production will be more than 30 years, millions of water cubic meters will be pumped out of the open pit, which is proportional to one third of the water reserves of Volyn region. Since 1994, the Institute has been monitoring the impact of the open pit excavation on the regime of groundwater and undergroundwater levels within the Ukraine's adjacent territory. IWPLR performed a predictive modeling and found out that the Khotyslavske deposit would have a significant impact on the natural waters of Shatsk Lakes area. It was established that the depression funnel will have a much larger radius than it declared in the EIA (Environmental Impact Assessment) of the Republic of Belarus [11]. The zone of impact includes the lakes of Svyate, Velikhov, the Turske reservoir and a significant number of settlements on the territory bordering Belarus (Fig. 5).

Provided that the rate of warming continues, which will worsen the water feeding of the pressure aquifer, there is a high probability of a progressive increase in the impact of Khotyslavsky open pit excavation on the groundwater and undergroundwater levels of Shatsk Lakes area and lowering water levels in the lakes of Shatsk Group.

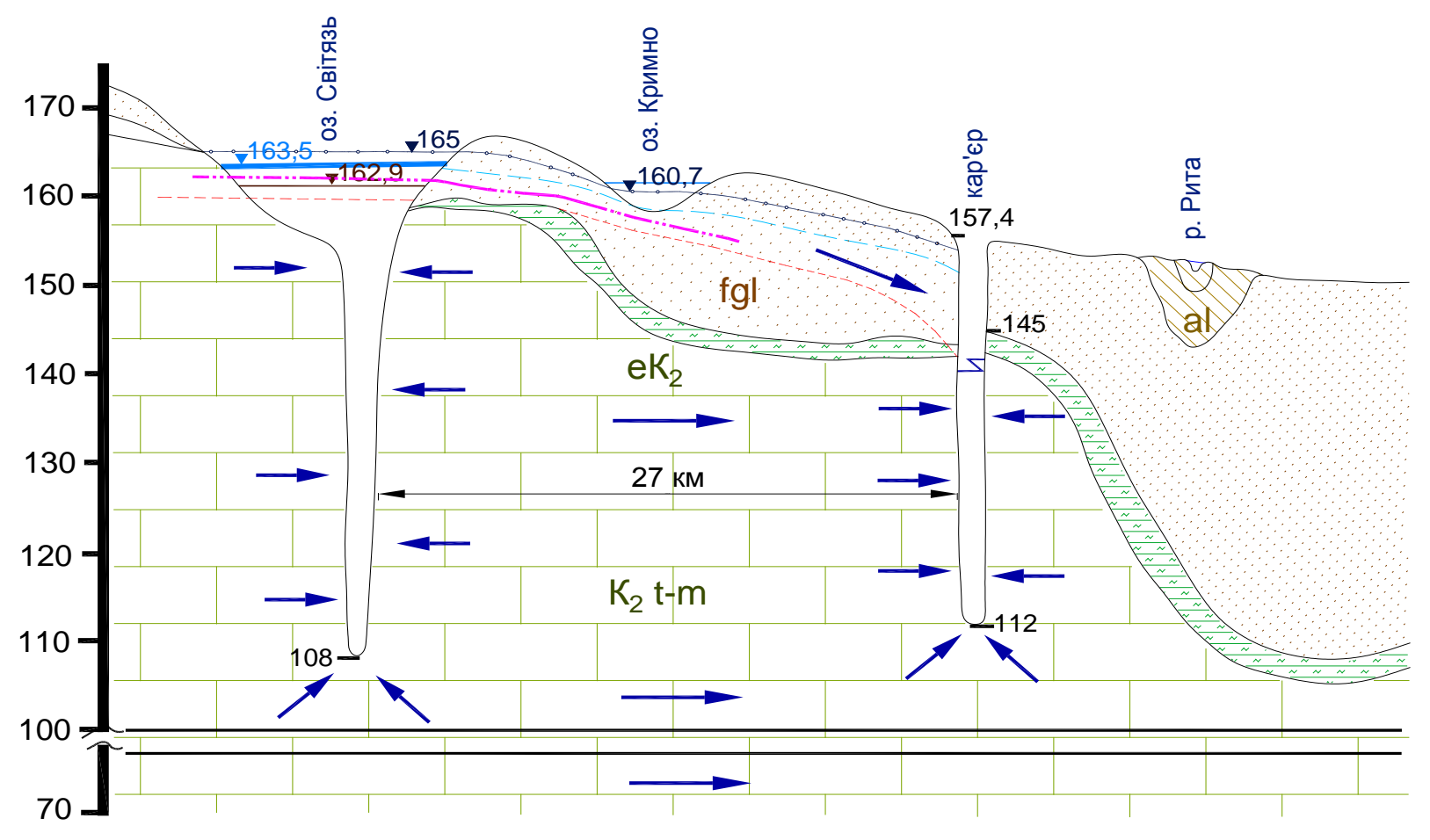

Умовні позначення:
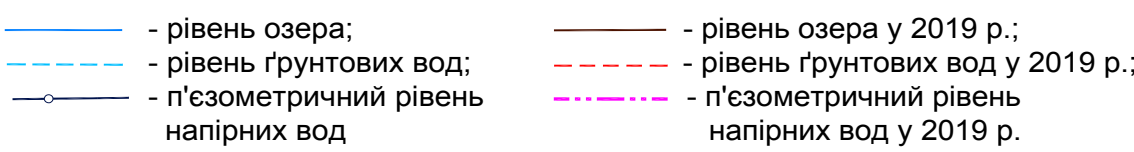

Fig. 5. The scheme of pressure and ground waters discharge by the lakes. Svityaz - Khotyslavsky open pit:... - lake level; ... - groundwater level; ... - piezometric level of pressure waters; ... - lake level in $2019 ; \ldots$ - groundwater level in 2019; ... - piezometric level of pressure waters in 2019.

Land reclamation systems. As a result of the analysis of operation and technical condition of the reclamation systems in the territory of Shatsk Lakes area their influence on the formation of water supply in the investigated territory and technical capacity of engineering infrastructure as to the accumulation and redistribution of water resources was determined.

Current operating schedules of local reclamation systems provide collection, drainage and removal of water from the territory of Shatsk NNP and do not provide for the possibility of accumulation of these waters with their subsequent use for water regulation. Therefore, the reconstruction of drainage systems aimed at their capability to provide necessary irrigation can be considered as one of the effective measures to improve the water supply of Shatsk Lakes area, especially in the second half of the growing season.

First of all, Kopaivska drainage system needs reconstruction. Reconstruction and modernization of this system into a complex irrigation system will turn it into one of the main means of water regulation 
(accumulation, redistribution, minimization of water discharge) and conservation of water resources of Shatsk Lakes area.

Water consumption. The current water consumption in Shatsk district is more than 1 million $\mathrm{m}^{3}$. The development of tourism in the area has significantly increased the water usage load in the water source, Shatsk Lakes. It is estimated that the development of tourism results in water consumption of at least $5-7 \mathrm{~m}^{3}$ per year.

It is mainly seasonal in nature, leads to additional load on groundwater and causes the transfer of groundwater to surface. As a result, the feeding conditions of aquifers, their regime, as well as the regime of surface runoff and, ultimately, the water balance on a regional scale are changing dramatically.

These processes are also accelerating due to the increasing use of groundwater for irrigation. Thus, in 2019 , the area of officially registered lands in Shatsk district of Volyn region for the cultivation of moistureloving crops (blueberries) was about 500 hectares, for irrigation of which at least 300-750 thousand $\mathrm{m}^{3}$ of water is annually used depending on the available natural moisture supply. Therefore, the greatest load on the aquifer occurs in the summer months, i.e. during the period when the lakes need the most groundwater. Due to the fact that the area of blueberry plantations is planned to triple, the groundwater intake will also increase and reach 1.35-1.5 million $\mathrm{m}^{3}$ per season [12-15].

Thus, active economic activity in this region is one of the important factors influencing the water regime of groundwater and surface water. Further intensification without a proper environmental impact assessment can lead to unpredictable and irreversible negative consequences.

Therefore, the implementation of water rational use and protection measures, as well as the implementation of water use within the legal framework in compliance with environmental standards and safety measures will significantly increase the efficiency of water management and will promote the sustainability of the nature reserve facilities in the territory of Shatsk Lakes area.

\section{Conclusions}

Based on the results of observations, scientific generalizations and conclusions, it was established that the process of Shatsk lakes shallowing is due to a set of factors, the most important of which is global climate change.

Climate change, as a result of which the value of HTC decreased from 1.4 in 1991 to 1.01 in 2018 and to 0.95 in 2019, led to a significant increase in total evaporation, which in turn led to a decrease in precipitation feed of the lakes, soil water and infiltration feeding of groundwater and, accordingly, decrease in water levels in lakes, groundwater and undergroundwater.

Increasing groundwater intake and uncontrolled undergroundwater drainage on the drainage systems are intensifying the process of lowering groundwater levels and hydraulically associated water levels in lakes and groundwater levels.

The further excavation of Khotyslavsky deposit of construction materials (Republic of Belarus) will be a special threat as to the further deterioration of the water regime in the territory of Shatsk Lakes area due to the progressive increase in water removing from it.

Minimization of the impact of these and other factors influencing the lowering of water levels in Shatsk lakes is possible providing the development and implementation of a set of adaptation measures, the main of which should be reconstruction and modernization of drainage systems into complex irrigation systems, reduction of groundwater intake in the territory of Ukraine and cessation of open pit excavation, and accordingly, water removing from Khostislavsky open pit.

Control over the implementation of these measures should be ensured through establishing and permanent operation of a system of monitoring observations for groundwater and surface water levels.

\section{References}

1. Aktualno: chomu znyzyvsia riven vody ozera Svitiaz? [Topical: why did the water level of Lake Svityaz decrease?] Retrieved from https://voladm.gov.ua/new/ aktualno-chomu-znizivsya-riven-vodiozera-svityaz [In Ukrainian].

2. Zaleskyi, I. I. (2014). Shatske poozeria. Heolohichna budova ta hidroheolohichni umovy [Shatsk lake. Geological structure and hydrogeological conditions]. Lutsk: Eastern European National University. Vol. 1. [In Ukrainian].

3. Khomik, N. V. (2013). Vodni resursy Shatskoho natsionalnoho pryrodnoho parku: suchasnyi stan, okhorona, upravlinnia [Water resources of Shatsk National Nature Park: current state, protection, management]. Kyiv. [In Ukrainian].

4. Tsvietova, O. V., \& Diatel, O. O. (2016). Vplyv rozrobky karieru budivelnykh materialiv «Khotyslavskyi» (Bilorus) na khimichnyi sklad pryrodnykh vod [Influence of Khotyslavsky building materials quarry development (Belarus) on the chemical composition of natural waters]. Voda $i$ robochi mistsia: materialy Vseukrainskoi naukovo-praktychnoi konferentsii, prysviachenoi vsesvitnomu dniu vody: tezy dop. [Water and workplaces: materials of the All-Ukrainian scientific-practical conference dedicated to the World Water Day: abstracts]. Kyiv. (pp. 133-134). [In Ukrainian].

5. Romashchenko, M. Pytannia vody v Ukraini stalo pytanniam natsionalnoi bezpeky [The issue of water in Ukraine has become a matter of national security] Retrieved from https:// hromadske.radio/podcasts/hromadska-hvylya/pro-problemy-z-vodoiu-treba-krychaty-ekspert-rozpovivpro-znevodnennia-ta-zminy-klimatu [In Ukrainian]. 
6. Romashchenko, M. I., Khvesyk, M. A., \& Mykhailov, Yu. O. (Eds.) (2015). Vodna stratehiia Ukrainy na period do 2025 roku (naukovi osnovy) [Water strategy of Ukraine for the period up to 2025 (scientific bases)]. Kyiv. [In Ukrainian].

7. Romashchenko, M. I., Yatsiuk, M. V., Shevchuk, S. A., Shevchenko, A. M., Danylenko, Yu. Iu., Matiash, T. V., \& Sydorenko, O. O. (2018). Vodna bezpeka - zaporuka staloho rozvytku Ukrainy [Water security is the key to sustainable development of Ukraine]. Bulletin of Agricultural Science, 11, 177-185. doi: 10.31073/ agrovisnyk201811-22. [In Ukrainian].

8. Romashchenko, M. (18 April 2018). Ploshcha sukhoi i duzhe sukhoi zony v Ukraini za ostanni 25 rokiv zbilshylasia na $7 \%$ [The area of dry and very dry zone in Ukraine has increased by $7 \%$ over the last 25 years]. Day. [In Ukrainian].

9. Hutbrod, K., Adamenko T. et al. Mihratsiia klimatychnykh zon na pivnich [Migration of climatic zones to the north]. Retrieved from https://landlord. ua/wp-content/page/pid-udarom-stykhii-iak-mihruiutklimatychni-zony-v-ukraini/ [In Ukrainian].

10. Diatel, O. O. (2019). Formuvannia vodoobminu ta yoho prohnozuvannia v umovakh tekhnohenezu na meliorovanykh terytoriiakh Volynskoho Polissia: avtoref. dys. ... kand. tekhn. nauk: 06.01.02 [Formation of water exchange and its forecasting in the conditions of technogenesis in the reclaimed territories of Volyn Polissya: author's ref. dis. ... Cand. tech. Science]. Kyiv. [In Ukrainian].

11. Kommentaryy, predlozhenyia y zamechanyia ukraynskykh tsentralnыkh y mestnukh orhanov vlasty, druhykh zaynteresovannыkh orhanyzatsyi po OVOS proekta «Razrabotka melovoi zalezhy mestorozhdenyia "Khotyslavskoe» (II ochered) v Malorytskom raione Brestskoi oblasty» (2010).

[Comments, suggestions and remarks of the Ukrainian central and local authorities, other interested organizations on the EIA of the project "Development of the chalk deposit of the" Khotislavskoye "deposit (stage II) in the Malorita district of the Brest region]. [In Russian].

12. U Shatskomu raioni try firmy zaimaiutsia vyroshchuvanniam lokhyny. (2019). [In the Shatsky area three firms are engaged growing blueberries] Retrieved from https://shatsk. rayon.in.ua/news/121888-ushatskomu-raioni-tri-firmi-zaimaiutsia-viroshchuvanniam-lohini [In Ukrainian].

13. Khotsevych, N. D., \& Kotsan, N. N. (2018). Suchasnyi stan ta rozvytok ahropromyslovoho vyrobnytstva Volynskoi oblasti [Current state and development of agro-industrial production of Volyn region]. Scientific Bulletin of Kherson State University. Geographical Sciences Series, 8, 150-154. [In Ukrainian].

14. Volyn prodovzhuie naroshchuvaty vyrobnychi ploshchi pid plantatsiiamy lokhyny. (2018). [Volyn continues to increase production areas under blueberry plantations]. Retrieved from https:// superagronom.com/news/4560-volin-prodovjuye-naroschuvati-virobnichi-ploschi-pid-plantatsiyami-lohini [In Ukrainian]. 